\title{
A global modification in avifaunal behavior by use of waste disposal sites (waste dumps/rubbish dumps): A review paper
}

\author{
Zunaira Noreen $^{1 *}$ and Khawar Sultan ${ }^{1}$ \\ 1. Department of Environmental Sciences, University of Lahore, Defence Road Campus, Lahore-Pakistan \\ *Corresponding author's email: zunaira.norin@ gmail.com \\ Citation \\ Zunaira Noreen and Khawar Sultan. A global modification in avifaunal behavior by use of waste disposal sites (waste \\ dumps/rubbish dumps): A review paper. Pure and Applied Biology. Vol. 10, Issue 3, pp603-616. \\ http://dx.doi.org/10.19045/bspab.2021.100062
}

Received: 18/08/2020 Revised: 29/10/2020

Accepted: 02/11/2020

Online First: 19/11/2020

\section{Abstract}

Urbanization is associated with production of huge mass of waste dumped at landfills attracting a large number of birds for food subsidies hence transforming dumping sites into novel habitats. The exploitation of waste dumps by birds and resultant issues has been reported from all over the world. We carried out a review of literature since 1960s until present regarding bird species foraging at waste dumps and resultant impacts. The 151 reviewed articles showed presence of 67 bird species including 10 endangered species on various waste dumps of the world. The research trend shows intensive studies on waste dumps of coastal areas of developed countries with main focus on gull species of genus Larus. A few studies have also been conducted at inland waste dumps focusing on bird species (Kites, Vultures, Storks, etc.) other than gulls. The individual level impacts of foraging at waste dumps include changing foraging habits, plastic ingestion, triggering reproductive cycles, pathogen infection risks and development of new learning mechanisms. The seasonal abundances, population explosion, change in migratory routes, problem of superabundant, invasive and endangered species are all included in population studies. The interactions with humans include ecosystem services of scavenging, exposure to pathogenic microorganisms, strikes to aircraft and economic loss done in controlling birds at waste dumps. A knowledge gap of research work at the inland waste dumps is identified around the globe in general and in South Asian region in particular with only a few studies in this context. It is found that with changing management practices in developed countries intensity of problem is reduced over the time but it remains critical in developing countries.

Keywords: Behavior; Birds; Ecology; Food waste; Impact; Toxicology; Waste dumps

\section{Introduction}

Urbanization is associated with the production of waste containing significant amount of food leftovers. The use of food subsidies derived from these waste dumps/rubbish dumps has become the most important driver of ecosystem nowadays. The estimated waste production (including food waste) is 3 million tones daily throughout the world and it will reach to the 
level of 11 million tones till 2100 AD [1]. The food wastage per capita by consumers ranges 6-11 kg/year in sub-Saharan Africa and Southeast Asia to 95 to $115 \mathrm{~kg} /$ year in Europe and North America [2]. This huge amount of food waste is dumped on waste dumps/rubbish dumps along with the domestic and commercial waste, which attracts large number of wild animals including birds for feeding on this easily accessible food in time and space. The exploitation of waste dumps by vertebrate species has been documented in many regions of the world [3-7]. Plaza \& Lambertucci [8] made a significant contribution in this regard by documenting wild species belonging to all the vertebrate classes taking advantage of waste dumps and associated physiological and behavioral changes. They discussed about animals belonging to all vertebrate classes exploiting the waste dumps/rubbish dumps. The birds are the largest group of vertebrates affected by these rubbish dumps as 54 out of 98 vertebrate species found on waste dumps are birds as compared to 34 mammalian, 5 amphibians and 5 reptilian species [8]. So this study is designed to document the bird's species specifically exploiting waste dumps in different geographical regions of the world and find out the impact of forging at individual and population level in them.

\section{Methods}

We made the intensive research using Google Scholar, Science Direct and Scopus by entering various combinations of key words without restriction of year and geographical location. First we combined five words, birds, landfill, impact, behavior, population, secondly, birds, garbage dumps or waste dumps, impact behavior, and individual and thirdly birds, rubbish dumps, behavior, impact and global. We reviewed the top 1000 returns from each search engine to sort out the articles related to birds and waste dumps/rubbish dumps only. Finally, we performed a search in the literature cited in the articles we reviewed. Most matched articles were separated and categorized on the basis of years to find out number of studies in each decade from 1960 to-date. Furthermore, all selected articles were grouped based upon geographical locations to find out regions of the world where studies have been conducted and to identify the knowledge gaps. The articles were also divided in areas of research that have been investigated extensively. The avian species present in the literature were separated to find out the total number of species exploiting waste dumps around the world. Finally, the impacts of foraging of waste dumps/rubbish dumps were reviewed at individual and population level. The ecological impacts of foraging and interaction with human were also reviewed at the end.

\section{Results}

\section{Published literature}

We found 151 articles on potential impacts of rubbish dumps on 67 avian species around the globe including 10 species that have status of threatened, endangered or critically endangered. The study started in the middle of twentieth century, a time when waste production begins to increase in various developed and developing countries of the world and continued until the present (Figure 1). There is gradual increase in the number of published studies since 1960s with the research work reaching at its peaked in the first decade of this century and then declined in present decade. This trend is most likely due to the better management of waste at waste dumps/rubbish dumps in the developed world where most of studies in this context have been done. There has not been much contribution on the topic from the developing world. It is, however, likely to increase over time as the impact of urban waste on birds is started to be reporting from many countries of Asia (Sri Lanka \& Pakistan) and Africa. 


\section{Types of research}

We found that research about the impact of waste dumps on birds have been done at both individual and population level. The individual level studies include foraging pattern, diet analysis, studying breeding parameters, behavioral adaptations, toxicology and transmission of pathogens while the seasonal abundance, population explosion, changing movement patterns, bird strikes to air craft and impact of waste dumps/rubbish dumps on threatened species are included in population level of study. The ecological interactions like problem of invasive species and interactions with human like benefits of scavenging and economic loss have also been studied have also been studied (Figure 2).

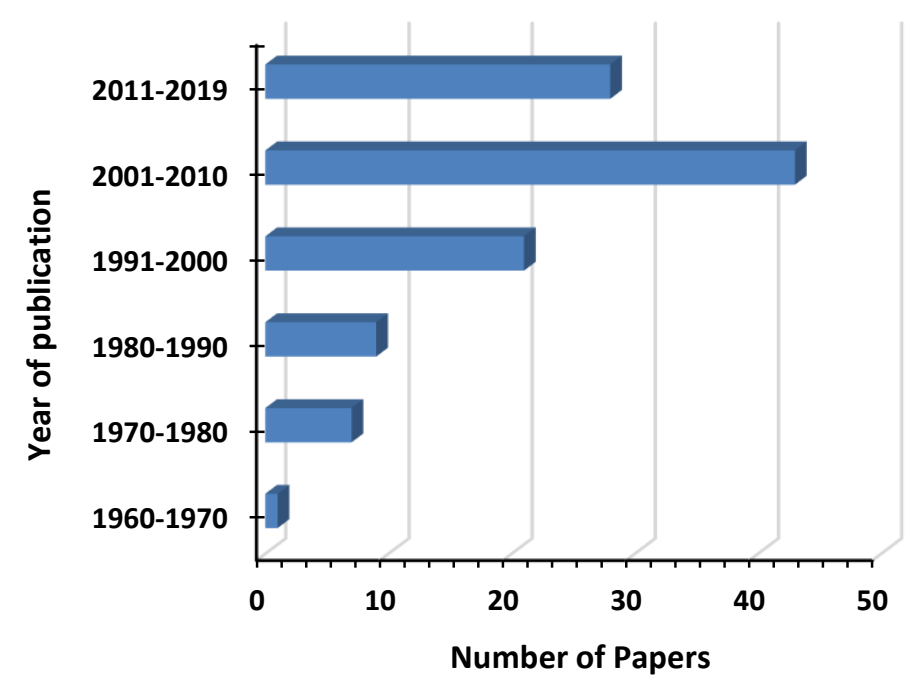

Figure 1. A decadal change in reviewed literature from 1960 till date

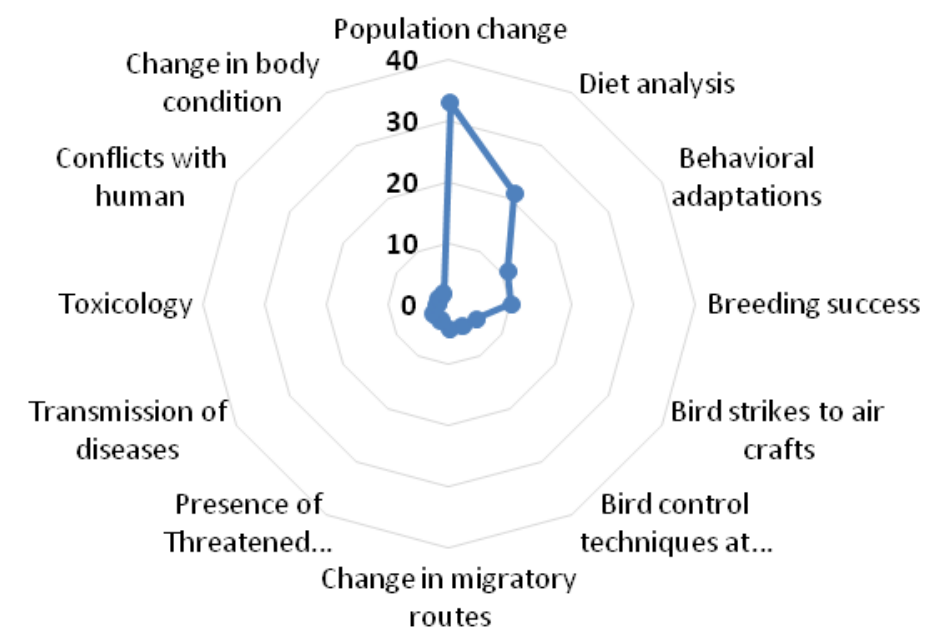

Figure 2. Shows the spider chart displaying variety of topics in relation to bird studies on landfills or urban waste disposal sites. Bird population change is the most investigated topic of all followed by bird diet analysis 
Geographic Areas where research has been conducted

Most of the studies on this issue are carried out in Western European countries (Figure.3). A significant contribution is also made by US but only a few studies are reported from other continents such as South America, Australia and Africa. The Asian region, being the largest continent in both land area and population, reported only one percent of study. South East Asia with largest populated and developing countries with poor system of waste dumping finds only $1 \%$ study conducted in Sri Lanka and Pakistan. Plaza and Lambertucci [8] in his review reported a gap in this context in Southeast Asia but now research has been started.

\section{Discussion}

Impact of waste dump foraging on birds at individual level

Abundance of huge population of birds on smaller

area

The availability of ample food supply on waste dumps/rubbish dumps attract huge number of birds congregating in a very small area. The presence of 699,350 birds of 42 species and 805, 684 birds of 41 species was reported on different waste dumps of Ohio, in the US in one year $[9,10]$. Even higher abundances reported on waste dumps/rubbish dumps of Tampa Bay and Virginia supporting and 90,000 and 112,693 birds of different species at any moment of time in year [11, 12]. A huge abundance of 847 Black kites (Milvus migrans) was reported on refuse dumps in Spain and Rome [13-15]. In Tokyo abundance of Jungle crow (Corvus macrorhynchos) on garbage dumps increased conflicts between man and wildlife [16]. Annorbah \& Holbech [17] also reported the abundance of the Hooded Vulture (Necrosyrtes monachus), Pied Crow (Corvus albus), and Cattle Egret (Bubulcus ibis) on the waste dumps of Ghana University. In
Greenland abundance of Common raven (Corvus corax) also increased significantly by using anthropogenic food from waste dumps [18]. In Brazil, Novaes \& Cintra [19] reported that population of Black Vulture (Coragyps atratus) and Turkey Vulture (Cathartes aura) is being sustained by rubbish dumps present in area. Such abundance of birds cannot only increase the pathogen infection risk within population but can also transfer this infection to human beings living in close proximity [20,21]. The presence of birds in huge number can pose problem to building and fresh water resources present near waste dumps by excreting their feces at these places. The noise of thousands of birds can cause nuisance and increase the pollution [20]. Moreover if the waste dumps are present in the close proximity of airports it can pose problem of air strikes which can lead to financial and life losses in human [4, 22-24]. Ecologically it can lead the problem of superabundant species which can cause the life threat to the local fauna in the area [25].

\section{Impact on foraging patterns}

Increasing Percentage of garbage in diet

The conventional and isotopic analysis of diet of many bird species foraging on waste dumps showed that they shift their diet from natural resources towards the garbage present on the rubbish dumps. For example in White storks (Ciconia ciconia) $77 \%$ of diet consists of material derived from food left over by humans [26]. Similarly, 54-69\% diet of Kelp gulls (Larus dominicanus) and $82 \%$ diet of Silver gulls (Larus novaehollandiae) consisted of food items derived from garbage [27, 28]. The 90\% stomach contents of (gullery) of Yellow-legged gulls (Larus michahellis) also consisted of food items obtained from rubbish dumps and fisheries discard [29]. The diet of a threatened avian species Egyptian vulture (Neophron percnopterus) found to be consisting of 50\% of food items obtained from rubbish dumps 
[30]. The scraps of food particles like meat, fish, chicken, fruits, vegetables, eggs, offal and cheese present in waste are of poorer quality but have the highest fat, protein content per gram and caloric value and the compared to a range of natural dietary items [31-33]. It is observed that different avian species can use this human produced waste when natural food is scarcer. This adaptation makes some species more successful as compared to those not foraging on garbage and results in sustaining and exploding population. The global increase in gull's population by exploiting waste dumps is a classic example.

\section{Ingestion of plastic material from rubbish dumps}

The birds, where find the food subsidies having high caloric value from waste dumps also come in direct contact with novel items present there and fill their stomachs with these items taking them food. The reason is that with passage of time the composition of human waste has been changed from food discards to a material full of plastic, glass, metals and many other types of exotic materials. Calle and Gawlik [34] reported that in the Sacred Ibis (Threskiornis aethiopicus), $58 \%$ of stomach contents consisted of items like plastic, glass, bacon, hot dog, and pellet meal. Bond [35] also reported that the diet composition of Herring gulls (Larus argentatus) showed huge transformation from natural diets to plastic debris in last 30 years. Similarly the stomach contents of Black vulture and Turkey Vulture were also found to be consisting of plastic and synthetic material ranging from $34 \%$ to $83 \%$ of total mass of regurgitates [30]. Torres-mura et al. [36] found that in regurgitates of Turkey Vulture the plastic material was found in $78 \%$ pellets of coastal and $83 \%$ pellets of inland area. The ingestion of plastic material can increase in mortality rate of birds consuming it. For instance, the consumption of poison from carcasses plastic and exotic materials [37, 38] by scavenger species i.e. Condor and Vultures has reduced their population drastically from globe [39]. Moreover the changes of scavenging to consumption of junk have resulted in ruining of the conservation efforts for rehabilitation of these species. The death of chicks and failure of conservation programs of Californian condor (Gymnogyps californianus) by consumption of the junk is one example $[30,39,40]$. The long term impacts of plastic ingestion should be investigated at large scales in species other than vultures and condors.

\section{Triggering reproductive cycle}

The breeding success of birds foraging on waste dumps is enhanced by constant utilization of enormous food supply. For example in White storks the continuous foraging at waste dumps reduced the time of sexual maturity from 4.9 to 2.9 years in one decade and also increased clutch size [41, 42]. Similarly in Glaucous gulls (Larus hyperboreus) fledging rate of a colony present within $10 \mathrm{~km}$ of waste dump was 2.9 times more than the colony present $75 \mathrm{~km}$ away from waste dump [25]. The direct correlation was also proved by other studies. For example in Herring gulls after closure of a waste dumps, the clutch size was reduced from 2.9 to 2.7 per breeding pair accompanied with reduction in Hatching and fledging rate also up to $75 \%$ to $46 \%$, respectively [43]. In Herring gulls mean production of young per breeding pair was decreased by $49.1 \%$ [44]. Kilpi \& Ost [45] also reported that the egg size and growth of hatchlings of Herring gulls was also reduced after closure of waste dump present nearby of colony. Some studies showed a contrasting effect that Herring gulls feeding on human refuse had lower reproductive success, measured as clutch size, hatching success and fledging success, as compared to feeding on natural prey [46]. In Western Gulls (Larus occidentalis) foraging on garbage also 
reported to produce lower hatching and fledging success, decreased the normal chick development, and shortens life spans [47]. So what is actual impact on breeding it is area of further research. Is it species specific that in some species it boosts up reproductive success and in others it is reduces? The other thing is whether it is geographic area specific i.e. facilitating breeding success in same species in one region of the world and decreasing in others? Or there are also other factors (like composition and amount of waste consumption, weather conditions, and intra-and inter-specific competition) that decide to increase or decrease reproductive success.

\section{Toxicology}

The food present on waste dumps/rubbish dumps and surrounding soils can have elevated amount of heavy metals derived from different sources of waste that may accelerate metal accumulation in avian species roosting, feeding and breeding there. The blood analysis of White storks showed a higher concentration of heavy metals, i.e. $\mathrm{Pb}$, $\mathrm{Se}, \mathrm{Hg}$, As and $\mathrm{Cd}$ than background levels which transferred to next generation and level of $\mathrm{Pb}, \mathrm{As}$, and $\mathrm{Hg}$ were 4.5, 10.2, and 2.8 times higher, in chicks living in colonies near a waste dumps/rubbish dumps than natural habitats [48]. Casa-Resino et al. [49] reported that analysis of antioxidant biomarkers in White stork hatchlings living on waste dumps/rubbish dumps also showed higher activity of glutathione and glutathione S-transferase in blood as compared to hatchling found in natural habitats. The chicks and eggs from nests of Black kites exposed to emissions from a solid-waste incinerator have higher lead concentrations when they were closer to the incinerator [50]. Sorais et al. [51] reported that the exposure of Halogenated flame retardants (HFRs) is increased many times in the Ring-billed gulls roosting and feeding on waste dumps/rubbish dumps. The exposure to Poly brominated diphenyl ethers also increased in the male Ring-billed gulls in a colony found near waste dumps/rubbish dumps [52]. These physiological changes are indicator of accumulation of heavy metals in blood of these birds which can be lethal in some cases. Similarly the lead toxicosis lead to decline in population of critically endangered Californian condor causing mortality of $26 \%$ juveniles and $67 \%$ adults [53]. The long term effects of bioaccumulation of these metals are not fully known and a knowledge gap is found here. The 67 species are found on the rubbish dumps but the toxicology is studied in only 4 to 5 species. The study is of utmost important and need of time.

\section{Behavior modifications for best exploitation of waste dumps Piracy}

Intra- and inter-specific Kleptoparasitism and piracy is a common strategy of stealing food on waste/rubbish dumps. For example, the Great black-backed gulls (Larus marinus) are most successful pirates at all stages of life $[54,55]$. The Intra- and inter-specific piracy is also observed in Black kites [15] Hooded Vulture Cattle Egret and Pied Crow with species being successful in pirating is more successful in scavenging with increasing chance of maximum exploitation of food from waste dumps [17].

\section{Switching to new learning mechanism}

The dumping of fresh waste on waste dumps in six days of week with one day break induced changes in memory of Herring gulls so that they become able to memorize the days of week by learning that Sunday is an off day and fresh food is not available on waste dumps $[56,57]$. By keeping this clue in mind, only a few adult gulls are present on waste dumps/rubbish dumps on Sundays whereas several hundreds of gulls gather during the weekdays (working days) in connection to arrival of fresh waste. Moreover, on Monday morning gulls arrive at waste dumping site in flocks very late 
because first lorry taking garbage arrives late. Sazima [58] also observed such a type of novel behavior in Black vulture on waste dumps in Brazil with tearing and eating food contained in plastic bags present on waste dumps. The analogy between opening plastic bags and carcasses made these vultures to take plastic bags as carcasses and open and eat all types of material like towel, clothes and others from them. It has made these vultures vulnerable to hard objects that can cause death of individuals by blocking throat hence causing harm to species.

\section{Impact of waste dump foraging on birds at} population level

\section{Population explosion of gull species around the globe}

The increase in breeding success of birds by using excessive food from waste dumps/rubbish dumps can lead to uncontrolled growth resulting in population explosion creating many ecological and economic problems. In Bristol channel it was observed that five gull species, Herring gulls, Lesser black -backed gulls (Larus fuscus) [3], Great Black-backed gulls, Common gulls (Larus canus) and Black- headed gulls (Larus ridibundus) increased to large extent by using food from different waste dumps [4, 5]. The population of Yellow-legged gulls (Larus michahellis) also reported to be increased exponentially on French and Spanish Mediterranean coast and Bay of Biscay from 1920 to 1980 and from 1982 to 2006, respectively [7, 29, 59, 60]. Spain has also witnessed the abundant population growth of Audouin's gulls (Ichthyaetus audouinii) on different refuse dumps [61]. In the New York bight an increase in Herring gulls and Great black-backed Gulls population was reported on different waste dumps [62]. The population of Kelp gulls also increased in many countries all along the coast of South America using the fisheries discards and human refuse [63]. The trend of increasing population of Silver gulls also reported from Australian continent as it created problems to human interests and posed economic losses in greater Sydney [64].

Population explosion species other than gulls

The population explosion of avian species other than gulls was also observed in different areas of world. Olea and Baglione [65] reported that the refuse tips in Leon, Spain, have an important role in expanding breeding population of Rooks (Corvus frugilegus) from $2.3 \%$ to $3.7 \%$ in 26 years. In Spain the population of White storks also increased by $75 \%$ from 1987 by using anthropogenic food [41]. Similarly, in Poland the population of White storks also increased at the waste dumps [26]. Calle \& Gawlik [34] reported that the population of introduced Sacred Ibis increased so much in Florida, USA, by use of anthropogenic food from waste dumps.

Change in migratory routes /Establishment of new colonies in nonnative areas

The establishment of waste dumps at migratory routes of birds has resulted in establishment of colonies of birds in areas where once they were migratory. Formerly, White Storks spent summer season in European countries, migrating during winter towards breeding grounds in North Africa and Central Asia [66]. Tortosa et al. [41] reported that from September to December (a time of winter migration) $80 \%$ of population of Storks was present in Spain rather than migrating to breeding areas. This trend was also observed in many other western European countries along the migratory routes. Moreover, it is also observed that a new breeding population has established on the South African waste dumps where not a single breeding colony was present earlier [26]. In Iberia, it was also found that the White storks have become resident in the area for whole year [67]. This change in migratory 
strategy was so beneficial for breeding success of storks that survival rate of chicks of non-migrating storks (resident) was much higher than migrating population. Rotics et al. [68] reported that improvement in survival rate of chicks increased the population in the Europe where once it was threatened. Thus the presence of waste dumps changed the biology, breeding, wintering ecology and migration strategies of this species. Thus the waste dumps can help in sustaining the population of species but total dependence of such species on the waste could be devastating because future establishment of population of these birds depends upon presence e and absence of waste dumps in area. Another aspect of this change is establishment of new colonies of birds in areas near waste dumps where no population was present formally which can be harmful for local fauna by increasing competition of resources. The establishment of Kelp gull breeding colony in the De La Guardia Islands, Argentina, is one example of this change [69]. The migration change has been reported only in White storks but it could be present in other 67 species reported on waste dumps which is a question needed to be answered by research.

\section{Ecological impacts of waste dump foraging Problem of invasive species}

Ecologically the foraging at waste dumps by birds created many problems. The invasive species introduced in new areas grew abundantly by exploitation of food subsidies and become a problem species. These problem species not only threat the local fauna and flora by competing for resources but also prey on them which can cause threat to their survival. For instance the superabundant Yellow-legged gulls in Mediterranean basin became problem for native fauna and flora and also causing conflicts with human interests [59]. These species attacked on endangered and threatened fauna of area for food. The attack of Glacous gulls on waterfowls in Alaska is another example where this problem species become danger for local bird species [25]. Sacred ibis is another example which was introduced in the US from Africa but its population exploded exponentially by use of anthropogenic food from waste dumps and it became so problematic that an eradication program was started for its control [34]. Another interesting example is also seen in Kelp gulls attacking on whales on the coastal areas of Argentina for food. It is observed that marks of poking are observed in $99 \%$ of whales present in area which is harmful for the whales [70].

\section{Impact on endangered species}

Historically, the feast of foraging on carcasses from waste dumps now has changed to havoc for globally threatened species of vultures and condors. Houston et al. [39] reported that all seven species of vulture and condors are eating and collecting junk food like plastic, glass, metal objects, bottle tops, sticks, grass, small rocks, wool, and fur, in their nests throughout the world from rubbish/waste dumps. These novel items especially glass and metal edges are leading to increase the mortality rate of young ones and even adult vultures resulting increasing the peril of extinction of already globally threatened species. Similarly, Rideout et al. [53] found that in critically endangered California condor the one important factor for failure of reintroduction efforts was ingestion of trash containing harmful materials from waste dumps /rubbish dumps which caused mortality of $73 \%$ of nestlings. But an opposite trend is observed by [71], that the largest population of Egyptian vulture is being sustained by the waste dumps of Socotra, Yemen where it is playing mutualistic role with reducing the discards like carcasses etc. This ecosystem service and availability of carcasses has led to the stabilization of population of this endangered species in the area while its 
number is drastically decreasing from other areas of world. According to Tauler-Ametller et al. [30] that population of Egyptian vulture is being sustained by waste dumps as diet of many breeding pairs consist of $25 \%$ to $50 \%$ of food items obtained from waste dumps/rubbish dumps and once decreasing population start to increase in area. It shows that it is composition of waste that affects the population increase or decrease in these scavenging species. Historically where these waste dumps/rubbish dumps have played important role in sustaining and flourishing the population of these scavenger species from centuries, now these waste dumps are becoming death sentence for these species as composition has changed from organic waste to novel materials which also contain poison in many cases. If the composition of waste remains changing in same way it will cause havoc to established population of many vulture species like Egyptian vulture and other increasing the extinction rate of all these species.

\section{Interactions with human \\ Ecosystem services from scavenging species}

Scavenging is beneficial for man as it reduces the meat and fisheries leftover from abattoirs and waste dumps and helps to clean the environment. Many avian species like Hooded Vultures, Marabou Storks (Leptoptilos crumeniferus), Pied Crows, and Black Kites, is witnessed scavenging on waste dumps helping in reducing carcasses [17, 72]. Pomeroy [72] observed that scavenging species in Uganda consume biomass equal to $100,000 \mathrm{~kg}$ and 750 tons annually. This consumption is beneficial for bird species as it provide food source and results in some cleanliness of the environment. Gangoso et al. [71] also reported similar situation that endangered Egyptian vulture is playing mutualistic role in Socotra, Yemen for reducing up to $22.4 \%$ of the organic waste annually produced in towns.

\section{Pathogen infection risk}

The foraging at waste dumps can cause the outbreak and transmission of different diseases from birds to the wild animals and even human beings living in proximity of waste dumps. The spreading of and Salmonella spp and Escherichia coli are examples of pathogen infections [20]. The prevalence of Campylobacter in Yellowlegged gulls and Salmonella species in American black vultures is directly proportional to quantity of refuse consumption from waste dumping sites [21]. These bacterial species do not affect the health condition of birds in which they are found but these birds can act as carriers of these bacterial species resulting in transmission of disease [73].

\section{Deteriorating water quality}

The birds roosting over fresh water reservoirs near waste dumps can deteriorate water quality by their feces and make water quality unsafe for human consumption [20].

\section{Economic losses due to Strikes to aircraft}

The gulls and other species foraging at waste dumps in the proximity of airports poses serious problems due to strikes to civil and military air traffic [4, 22-24]. In UK gulls are responsible for $42 \%$ of all bird strikes [5]. In the USA from the year 1987 to 1991, 28\% of bird strikes were due to waste dump related colonies. The night and dawn time strikes comprised of $12 \%$ and $20 \%$, respectively, of the total strikes. These gulls are equally active at day and night time for foraging on waste dumps and can move 30 miles in search of food, hence, can cause risky strikes to aircrafts [24, 74, 75]. The population of Black Vulture and Turkey Vulture in proximity of urban areas in Brazil has become a potential cause of strikes to air craft. These two vulture species have become second important bird group causing 65 strikes with air craft from 2000 to 2012 [19]. 
In Brazil, for example, 65 bird strikes were reported in 12 years and the cost of one strike is equal to US\$750,000 (CENIPA, 2012). Similarly, when different avian species become a problem species in areas near waste dumps lots of efforts is done to control them by combination of different techniques [75, 76]. It does lots of financial loss as well as labor. It is estimated that the cost of bird control reaches to US\$120000 annually, in the UK [77].

\section{Conclusion}

In this review, it is found that the exploitation of waste dumps by birds for food has different impacts at both individual and population level. Most of the reviewed studies focus on seasonal abundances, population explosions and study of reproductive cycles. A few studies also focus on the toxicology, pathogen infection risk, conflicts with human and bird control method on waste dumps. This review also found that there are knowledge gaps that require scientific investigation. Firstly, the poisoning caused by waste dumps may lead to increase in mortality of birds of particular species foraging here. This problem can be more critical in developing countries with poor waste handling and open dumping system. Man has witnessed the extinctions of many species of vultures and condors worldwide. Although some work has been done in this context, there is need of detailed research work in the field of toxicology on how fumes produced by fires and chemicals present effect the birds' health. Secondly, most of the published studies focus on a set of species such as gull, stork, kites and vulture, etc., but there is a lack of literature on other bird species feeding on waste dumps, hence a knowledge gap exists here. Thirdly, there is a significant research work available on impact of waste dumps on the coastal avian birds, but a very few studies have documented waste materials impact on the non-aquatic and terrestrial communities of birds. So an attention is needed towards the terrestrial waste dumps and avian species being affected by them. Furthermore, the long term effects of foraging at breeding parameters population explosions and ingestion of micro plastic from waste dumps are areas of further research.

In Europe and North America, where most studies have been conducted, it is found that the scale of problem was very high in last two decades but now the problem is under control due to management practices that are replacing waste dumps with incinerators. But in developing countries, large amount of waste material and poor disposal system the severity of issue is a question worth answering. An intensive research is required in the developing countries of Asia and Africa, especially South East Asia, to document the intensity of problem and the scale of impact on wild avifauna feeding on items from waste dump site.

The actual future impacts of waste dumps on birds at global level are difficult to predict because of the unavailability of complete data. About $99 \%$ data is available from Europe and North America where the problem has already been adequately addressed and is being further controlled by changing management practices. The Only $1 \%$ data is available from developing countries where the waste production is high and the management practices are poorer so it is very difficult to assess actual status of problem. Another aspect of this issue is that the European legislation by the European Parliament which aims at reduction of waste to zero by 2020 , by replacing all waste dumps with incinerators is also controversial as many bird species have shifted from natural habitats towards the waste dumps and now if the waste dumps are closed what will be the next distribution pattern and conservation status of these species, to understand, it will be and new challenge of $21^{\text {st }}$ century for conservationists. 


\section{Authors' contributions}

Conceived idea: Z Nureen, Performed experiment: Z Nureen \& K Sultan, Analyzed data: Z Nureen \& K Sultan, Wrote paper: Z Nureen \& K Sultan, Reviewed the paper: K Sultan.

\section{Acknowledgments}

We would like to thank faculty members for support, inspiring discussion and encouragement to complete the manuscript. We also wish to thank Mr. Khushi Muhammad for his help during field work. This work is part of the project to carry out baseline situation and the impact of urban waste of wild avifauna in the northeastern part of Punjab.

\section{References}

1. Hoornweg D Bhada-Tata P \& Kennedy C (2013). Environment: Waste production must peak this century. Nature News 502: 615-617.

2. Parfitt J Barthel $M$ \& Macnaughton S (2010). Food waste within food supply chains: quantification and potential for change to 2050. Philos Trans $R$ Soc B 365: 3065-3081.

3. Harris MP (1970). Rates and causes of increases of some British gull populations. Bird Study 17: 325-335.

4. Mudge GP \& Ferns PN (1982). The feeding ecology of five species of gulls (Ayes: Larini) in the inner Bristol Channel. $J$ Zool 197: 497-510.

5. Horton N Brough T \& Rochard JBA (1983). The importance of refuse tips to gulls wintering in an inland area of south-east England. J Appl Ecol 20: 751-765.

6. Martina A \& Gallarati M (1997). Use of a garbage dump by some mammal species in the Majella massif (Abruzzo, Italy). Hystrix 9: 1-2.

7. Jordi O Herrero A Aldalur A Cuadrado JF \& Arizaga J (2014). The impact of non-local birds on yellow-legged gulls (Larus michahellis) in the Bay of Biscay: a dumpbased assessment. Anim Biodiv Conserv 37: 183-190.

8. Plaza PI \& Lambertucci SA (2017). How garbage are dumps impacting vertebrate demography, health, and conservation. Glob Ecol Conserv 12: 9-20.
9. Belant JL Seamans TW Gabrey SW \& Dolbeer RA (1995). Abundance of gulls and other birds at landfills in northern Ohio. Am Midl Nat 134: 30-40.

10. Gabrey SW (1997). Bird and small mammal abundance at four types of wastemanagement facilities in northeast Ohio. Landscape Urban Plan 37: 223-233.

11. Patton SR (1988). Abundance of gulls at Tampa Bay landfills. Wilson Bull 100(3): 431-442.

12. Francoeur L \& Lowney M (1997). Bird abundance at accomack county southern landfill, melfa, Virginia, in relation to various management activities. In: Proceedings of the Eighth Eastern Wildlife Damage Management Conference 8: 140151.

13. Blanco G (1994). Seasonal abundance of Black Kites associated with the rubbish dump of Madrid, Spain. J Raptor Res 28: 242-245.

14. Blanco G (1997). Role of refuse as food for migrant, floater and breeding Black Kites (Milvus migrans). J Raptor Res 31: 71-76.

15. Giacomo U \& Guerrieri G (2008). The feeding behavior of the Black Kite (Milvus migrans) in the rubbish dump of Rome. $J$ Raptor Res 42: 110-118.

16. Kurosawa $\mathrm{R}$ Kanai $\mathrm{Y}$ Matsuda $\mathrm{M}$ \& Okuyama M (2003). Conflict between humans and crows in greater Tokyo-garbage management as a possible solution. Glob Environ Res 7: 139-148.

17. Annorbah NN \& Holbech LH (2012). Relative abundance, agonistic behaviour, and resource partitioning among three scavenging bird species in Ghana. Malimbus 34: 1-8.

18. Restani M Marzluff JM \& Yates RE (2001). Effects of anthropogenic food sources on movements, survivorship, and sociality of common ravens in the arctic. Condor 103(2): 399-404.

19. Novaes WG \& Cintra R (2015). Anthropogenic features influencing occurrence of Black Vultures (Coragypsatratus) and Turkey Vultures (Cathartes aura) in an urban area in central Amazonian Brazil. Condor 117(4): 650659. 
20. Benton C Khan F Monaghan P Richards WN \& Shedden CB (1983). The contamination of a major water supply by gulls (Larus sp.): a study of the problem and remedial action taken. Water Res 17: 789-798.

21. Plaza PI Blanco G Madariaga MJ Boeri E Teijeiro M L Bianco G \& Lambertucci SA (2019). Scavenger birds exploiting rubbish dumps: Pathogens at the gates. Transbound Emerg Dis 66: 873-881.

22. MacKinnon B Sowden R \& Dudley S (2001). Sharing the skies: an aviation guide to the management of wildlife hazards. Transport Canada, Ottawa, Ontario, Canada.

23. Belant JL Seamans TW Gabrey SW \& Ickes SK (1993). Importance of landfills to nesting herring gulls. Condor 95: 817-830.

24. Burger J (2001). Landfills, nocturnal foraging, and risk to aircraft. $J$ Toxicol Environ 64: 273-290.

25. Weiser EL \& Powell AN (2010). Does garbage in the diet improve reproductive output of Glaucous Gulls? Condor 112: 530-538.

26. Ciach M \& Kruszyk R (2010). Foraging of white storks Ciconia ciconia on rubbish dumps on non-breeding grounds. Waterbirds 33(1):101-104.

27. Smith GC Carlile N \& Louwerse I (1991). The Importance of Human Refuse as a Food Source for Silver Gulls. Aust Bird Watch 14: 24-27.

28. Bertellotti M Yorio P Blanco G \& Giaccardi M (2001). Use of tips by nesting Kelp Gulls at a growing colony in Patagonia. $J$ Field Ornithol 72: 338-348.

29. Ramos R Ramírez F Sanpera C Jover L, \& Ruiz X (2009) Diet of Yellow-legged Gull (Larusmichahellis) chicks along the Spanish Western Mediterranean coast: the relevance of refuse dumps. J Ornithol 150: 265-272.

30. Tauler-Ametller H Hernández-Matías A Parés F Pretus JL \& Real J (2018). Assessing the applicability of stable isotope analysis to determine the contribution of landfills to vultures' diet. Plos One 13(5): e0196044.

31. Pierotti R \& Annett C (1990). Diet and reproductive output in seabirds. Biol Sci 40: 56574.

32. Pierotti R \& Annett C (1991). Diet choice in the Herring Gull-constraints imposed by reproductive and ecological factors. Ecology 72: 319-328.

33. Oro D Genovart M Tavecchia G Fowler MS \& Martínez A (2013). Ecological and evolutionary implications of food subsidies from humans. Ecol Lett 16: 1501-1514.

34. Calle L \& Gawlik DE (2011). Anthropogenic food in the diet of the Sacred Ibis (Threskiornis aethiopicus), a non-native wading bird in southeastern Florida, USA. Fla Field Nat 39: 1-15.

35. Bond A (2016). Diet changes in breeding herring gulls (Larus argentatus) in Witless Bay, Newfoundland and Labrador, Canada, over 40 Years. Waterbirds 39: 152-158.

36. Torres-Mura JC Lemus M L \& Hertel F (2015). Plastic material in the diet of the Turkey vulture (Cathartes aura) in the Atacama Desert, Chile. Wilson J Ornithol 127: 134-138.

37. Green RE Newton IAN Shultz S Cunningham AA Gilbert M Pain DJ \& Prakash V (2004). Diclofenac poisoning as a cause of vulture population declines across the Indian subcontinent. J Appl Ecol 41: 793-800.

38. Ogada DL (2014). The power of poison: pesticide poisoning of Africa's wildlife. Ann N Y Acad Sci 1322:1-20.

39. Houston DC Mee A \& McGrady M (2007). Why do condors and vultures eat junk? The implications for conservation. J Raptor Res 41: 235-238.

40. Mee A Rideout BA Hamber JA, Todd JN, Austin G, Clark M \& Wallace MP (2007). Junk ingestion and nestling mortality in a reintroduced population of California Condors Gymnogyps californianus. Bird Conserv Int 17: 119-130.

41. Tortosa FS Caballero JM \& Reyes-López J (2002). Effect of rubbish dumps on breeding success in the White Stork in southern Spain. Waterbirds 25:39-43.

42. Tortosa FS Pérez L \& Hillström L (2003). Effect of food abundance on laying date and clutch size in the White Stork Ciconia ciconia. Bird Study 50: 112-115.

43. Pons JM (1992). Effects of human refuse on a nesting population of herring gull Larus argentatus in Brittany, France. Ardea 80: 143-150. 
44. Pons JM \& Migot P (1995). Life-history strategy of the herring gull: changes in survival and fecundity in a population subjected to various feeding conditions. $J$ Anim Ecol 64: 592-599.

45. Kilpi M \& Ost M (1998). Reduced availability of refuse and breeding output in a herring gull (Larus argentatus) colony. Ann Zool Fenn 35(1): 37-42.

46. Annett CA \& Pierotti R (1999). Long-term reproductive output in Western Gulls: Consequences of alternate tactics in diet choice. Ecol 80: 288-297.

47. Pierotti R \& Annett C (2001). The ecology of Western Gulls in habitats varying in degree of urban influence. Pages 307-329 in Avian Conservation in an Urbanizing World (J. M. Marzluff, R. Bowman and R. Donnelly, Eds.). Kluwer Academic Publishers, Boston, MA.

48. Casa-Resino DL Hernández-Moreno D Castellano A Pérez-López M \& Soler F (2014). Breeding near a landfill may influence blood metals $(\mathrm{Cd}, \mathrm{Pb}, \mathrm{Hg}, \mathrm{Fe}, \mathrm{Zn})$ and metalloids (Se, As) in white stork (Ciconia ciconia) nestlings. Ecotoxicol 23: 1377-1386.

49. Casa-Resino DL, Hernández-Moreno D, Castellano A, Soler RF \& Pérez-López M (2015). Biomarkers of oxidative status associated with metal pollution in the blood of the white stork (Ciconia ciconia) in Spain. Toxicol Environ Chem 97: 588-598.

50. Blanco G Jimenez B Frias O Millan J Davila JA (2004). Contamination with nonessential metals from a solid-waste incinerator correlates with nutritional and immunological stress in prefledgling black kites (Milvus migrans). Environ Res 94: 94101.

51. Sorais M Mazerolle MJ Giroux JF \& Verreault J (2019). Landfills represent significant atmospheric sources of exposure to halogenated flame retardants for urbanadapted gulls. Environ Int 135: 105387.

52. Gentes ML Mazerolle MJ Giroux JF Patenaude-Monette M \& Verreault J (2015). Tracking the sources of polybrominated diphenyl ethers in birds: Foraging in waste management facilities results in higher Deca
BDE exposure in males. Environ Res 138: 361-371.

53. Rideout BA Stalis I Papendick R Pessier A Puschner B Finkelstein ME Smith DR Johnson M Mace M Stroud R Brandt J Burnett J Parish C Petterson J Witte C Stringfield C Orr K Zuba J Wallace M \& Grantham J (2012). Patterns of mortality in free-ranging California Condors (Gymnogyps californianus). J Wildl Dis 48, 95-112.

54. Verbeek NA (1977). Comparative feeding ecology of herring gulls Larus argentatus and lesser black-backed gulls Larusfuscus. Ardea 65: 25-42.

55. Burger J Fitch M Shugart G \& Werther W (1980). Piracy in Larus gulls at a dump in New Jersey. In Proceedings of the Colonial Waterbird Group. Col Waterbirds 3: 87-98.

56. Monaghan P Metcalfe NB \& Hansell MH (1986). The influence of food availability and competition on the use of a feeding site by Herring Gulls Larus argentatus. Bird Study 33: 87-90.

57. Coulson JC Butterfield J Duncan N \& Thomas C (1987). Use of refuse tips by adult British herring gulls Larus argentatus during the week. J Appl Ecol 24: 789-800.

58. Sazima I (2007). From carrion-eaters to bathers' bags plunderers: how Black Vultures (Coragyps atratus) could have found that plastic bags may contain food. Rev Bras Ornitol 15: 617-620.

59. Vidal E Medail F \& Tatoni T (1998). Is the yellow-legged gull a superabundant bird species in the Mediterranean? Impact on fauna and flora, conservation measures and research priorities. Biodivers Conserv 7: 1013-1026.

60. Duhem $\mathrm{C}$ Roche $\mathrm{P}$ Vidal $\mathrm{E} \&$ Tatoni $\mathrm{T}$ (2008). Effects of anthropogenic food resources on yellow-legged gull colony size on Mediterranean islands. Popul Ecol 50(1): 91-100.

61. Blanco G \& Marchamalo J (1999). Postbreeding inland movements and use of refuse dumps by Audouin's and other gulls in Spain. Col Waterbirds 22: 307-309.

62. Washburn BE Lowney MS \& Gosser AL (2012). Historical and current status of 
Laughing Gulls breeding in New York State. Wilson J Ornithol 124: 525-530.

63. Yorio P Branco J O Lenzi J Luna-Jorquera G \& Zavalaga C (2016). Distribution and trends in kelp gull (Larus dominicanus) coastal breeding populations in South America. Waterbirds 39: 114-135.

64. Temby ID (2004). Silver Gulls: urban waste creates flying problems. Urban Wildlife: More Than Meets The Eye 153-158.

65. Olea PP \& Baglione V (2008). Population trends of Rooks Corvus frugilegus in Spain and the importance of refuse tips. Ibis 150(1): 98-109.

66. Blanco G (1996). Population dynamics and communal roosting of white storks foraging at a Spanish refuse dump. Col Waterbirds 19: 273-276.

67. Gilbert I Correia RA Silva JP Pacheco C Catry I Atkinson PW \& Franc AM (2016). Are white storks addicted to junk food? Impacts of landfill use on the movement and behaviour of resident white storks (Ciconia ciconia) from a partially migratory population. Mov Ecol 4:7.

68. Rotics S Turjeman S Kaatz M Resheff YS Zurell D Sapir N \& Wikelski M (2017). Wintering in Europe instead of Africa enhances juvenile survival in a long-distance migrant. Anim Behav 126: 79-88.

69. Frixione MG Casaux R Villanueva $C$ Alarcón PA (2012). A recently established Kelp Gull colony in a freshwater environment supported by an inland refuse dump in Patagonia. Emu 112: 174-178.
70. Fazio A Bertellotti $M$ \& Villanueva C (2012). Kelp gulls attack Southern right whales: a conservation concern? Mar Biol 159: 1981-1990.

71. Gangoso L Agudo R Anadón JD Riva MD Suleyman AS Porter R \& Donázar JA (2013). Reinventing mutualism between humans and wild fauna: insights from vultures as ecosystem services providers. Conserv Lett 6: 172-179.

72. Pomeroy DE (1975). Birds as scavengers of refuse in Uganda. Ibis 117: 69-81.

73. Ramos R Cerdà-Cuéllar M Ramírez F Jover L \& Ruiz X (2010). Influence of refuse sites on the prevalence of Campylobacter spp. and Salmonella serovars in seagulls. Appl Environ Microbiol 76: 3052-3056.

74. Baxter A James K Thompson R \& Laycock $H$ (2003). Predicting the birdstrike hazard from gulls at landfill sites. International Bird Strike Committee Warsaw IBSC26/WP-BAM5.

75. Baxter AT \& Allan JR (2006). Use of raptors to reduce scavenging bird numbers at landfill sites. Wildl Soc Bull 34: 1162-1168.

76. Cook A Rushton S Allan J \& Baxter A (2008). An evaluation of techniques to control problem bird species on landfill sites. Environ Manage 41(6): 834-843.

77. Allan JR (2000). The costs of bird strikes and bird strike prevention: Human conflicts with wildlife. Economic Considerations 18: 147-153. 